\title{
A Rövid Betegségpercepció Kérdőív magyar változatának megbízhatósági vizsgálata
}

\author{
Látos Melinda dr. ${ }^{1,2}$ - Lázár György dr. ${ }^{2}$. Csabai Márta dr. ${ }^{1}$ \\ ${ }^{1}$ Szegedi Tudományegyetem, Általános Orvostudományi Kar, Sebészeti Klinika, Szeged \\ ${ }^{2}$ Szegedi Tudományegyetem, Bölcsészettudományi Kar, Pszichológiai Intézet, Szeged
}

\begin{abstract}
Bevezetés: Interdiszciplináris kutatásokkal igazolták, hogy a páciensnek a betegségéról kialakított elképzelései meghatározó szerepet játszanak a gyógyulási folyamat sikerességében.

Célkitüzés: Vizsgálatunk célja az ezen elképzelések felmérésére kifejlesztett Rövid Betegségpercepció Kérdőiv magyar nyelvú változatának megbízhatósági és validitási vizsgálata krónikus betegségben szenvedő, daganattal küzdő és transzplantált páciensek körében.

Módszer: Keresztmetszeti vizsgálatunkban 490 páciens vett részt. A kérdőív validitásának vizsgálatára a Spielbergerféle Állapot- és Vonásszorongás Kérdőívet, a Beck Depresszió Kérdőívet és a Poszttraumás Növekedésérzés Kérdőívet alkalmaztuk, illetve felmértük a betegcsoportok életminőségét.

Eredmények: A kérdőív belső megbízhatósága, a teszt-reteszt megbízhatósága kiváló. A konstruktumvaliditást vizsgálva közepesen erős összefüggést találtunk a szorongás, a depresszió, a poszttraumás növekedésérzés, az életminőség és a Rövid Betegségpercepció Kérdőív között. A prediktív validitást vizsgálva igazolást nyert, hogy a betegségpercepció összefüggésben áll a vesemúködést jelző eGFR-szinttel $(\mathrm{p}=0,027)$. A kérdőív diszkrimináns validitását igazolta, hogy képes különbséget tenni a különböző betegcsoportok között.

Következtetés: A Rövid Betegségpercepció Kérdőív magyar verziójának reliabilitása és validitása a vizsgált populáción jónak mutatkozott. A kérdőív megbízható információt ad a pácienseknek a betegségükről kialakított elképzeléseiről. Orv Hetil. 2021; 162(6): 212-218.
\end{abstract}

Kulcsszavak: betegségpercepció, szorongás, depresszió, poszttraumás növekedésérzés, életminőség, validitásvizsgálat

\section{The reliability and validity of the Hungarian version of the Brief Illness Perception Questionnaire}

Introduction: Interdisciplinary studies confirm that patients' illness perception can have a substantial effect on the healing process.

Objective: The aim of this study was to assess the reliability and validity of the Hungarian version of the Brief Illness Perception Questionnaire in chronic disease, cancer, and transplant patients.

Method: 490 patients were assessed using the Spielberger Anxiety Inventory, the Beck Depression Inventory, Posttraumatic Growth Inventory and quality of life questionnaires.

Results: The scale showed good internal consistency, and the test-retest reliability was excellent. The Brief Illness Perception Questionnaire scores moderately correlated with anxiety, depression, posttraumatic growth and quality of life. Examining predictive validity, the questionnaire correlated with eGFR level $(\mathrm{p}=0.027)$. The discriminant validity of the questionnaire was supported by its ability to distinguish between different patient groups.

Conclusion: The reliability and validity of the Hungarian version of the Brief Illness Perception Questionnaire in the sample were excellent. The questionnaire turned out to be a useful psychometric tool in the measurement of illness perception.

Keywords: illness perception, anxiety, depression, posttraumatic growth, quality of life, reliability and validity

Látos M, Lázár Gy, Csabai M. [The reliability and validity of the Hungarian version of the Brief Illness Perception Questionnaire]. Orv Hetil. 2021; 162(6): 212-218.

(Beérkezett: 2020. július 21.; elfogadva: 2020. augusztus 23.) 


\section{Rövidítések}

ANOVA $=($ analysis of variance $)$ varianciaanalízis; $\mathrm{BDI}=($ Beck Depression Inventory) Beck Depresszió Kérdőív; BIPQ = (Brief Illness Perception Questionnaire) Rövid Betegségpercepció Kérdő́iv; eGFR = (estimated glomerular filtration rate $)$ becsült glomerulusfiltrációs ráta, mely a vese múködésének károsodását adja meg; EQ-5D-3L = (European Quality of Life) Európai Életminőség Kérdőív; FACT-G $=$ (Functional Assessment of Cancer Therapy - General) daganatos betegségek kezelésének funkcionális értékelése - általános; GIQLI = (Gastrointestinal Quality of Life Index) Gastrointestinalis Életminőségi Index; HIV = (human immunodeficiency virus) emberi immunhiányt előidéző vírus; IPQ = (Illness Perception Questionnaire) Betegségpercepció Kérdóív; IPQ-R = (Revised Illness Perception Questionnaire) átdolgozott Betegségpercepció Kérdő́iv; PTGI = (Posttraumatic Growth Inventory) Poszttraumás Növekedésérzés Kérdőív; SD = standard deviáció; STAI-S = (State-Trait Anxiety Inventory - State) Spielberger-féle Állapotszorongás Kérdőív; STAI-T = (State-Trait Anxiety Inventory - Trait) Spielberger-féle Vonásszorongás Kérdő́í; SZTE = Szegedi Tudományegyetem

Az utóbbi 30 év kutatásai bebizonyították, hogy a betegségreprezentációk nagymértékben meghatározzák a páciens viselkedését, érzelmi és hangulati állapotát, illetve a felépülés sikerességét [1-3]. Leventhal, Nerenz és Steele 1984-ben publikálták az önszabályozási modellról szóló elméletüket, mely szerint az egyének az egészségüket fenyegető helyzetekre kognitív és emocionális reprezentációkat generálnak [4]. A betegségészlelés keretein belül értelmezhetővé válnak a tünetek, a reprezentáció képet ad a betegségről, ami a megküzdési stratégiákra és a klinikai kimenetre is hatást gyakorol. A modell szerint folyamatos visszacsatolás történik az értékelőfolyamatok, a betegség alakulása és a megküzdési módok között. Kutatási eredményekkel igazolták, hogy a betegségpercepciók megváltozása pozitív hatású a myocardialis infarctuson átesett betegek felépülésében [5]. Amikor megvizsgálták, hogy vajon a betegség objektív súlyosságának vagy a betegségpercepciónak, a betegség által okozott hatások szubjektív érzékelésének van-e nagyobb hatása az életminőségre, az eredmények szerint a krónikus betegséggel való megküzdés szempontjából a betegségpercepció jelentősebb szerepet töltött be, mint a betegség súlyossága, illetve nem találtak összefüggést a betegség súlyossága és a betegség hatásának percepciója között sem [6-8].

A korai kutatások még interjús technikákkal próbálták feltérképezni a betegségreprezentációkat, majd megszületett az első objektív mérőeszköz, a Betegségpercepció Kérdőív (IPQ), mely öt kognitív betegségreprezentációt képes azonosítani: identitás - a betegség természetére vonatkozik, illetve azokra a tünetekre, melyeket a páciens a betegséggel összefüggőnek tart; okok - a betegség kialakulásával kapcsolatos személyes hit, vélekedés; idöbeliség - a betegség észlelt tartósságára utal; következmények - a betegség kimenetele, illetve rövid és hosszú távú hatásai; és kontroll - a betegség és a kezelés felett érzett kontrollra utal, hogy milyen mértékben hisz a páciens a gyógyulásában $[4,9]$. Az érzelmi reprezentáció olyan negatív reakciókat tartalmazhat, mint a félelem, a düh vagy a distressz érzése. Az újabb, átdolgozott kérdőív (IPQ-R) már tíz dimenzió mentén tudja értékelni az érzelmi és kognitív reprezentációkat, például megszületett a személyes és kezelési kontroll dimenziója [2]. A módosított kérdőív azonban nagyon hosszú, több mint 80 kérdést tartalmaz, ami bizonyos helyzetekben megnehezíti a tesztfelvételt (például korlátozott a rendelkezésre álló idő, a páciens súlyos betegséggel küzd, vagy magasabb életkorú). A kutatók alternatívaként a könnyen felvehető, kilenctételes Rövid Betegségpercepció Kérdőív (BIPQ) alkalmazását javasolják, melyet a betegség kognitív és érzelmi reprezentációjának gyors értékelésére fejlesztettek ki [10].

\section{A vizsgálat célja}

A jelen kutatásban a BIPQ magyar változatát és a kérdőív pszichometriai jellemzőit mutatjuk be krónikus, daganatos megbetegedésben szenvedó és vesetranszplantáción átesett személyek mintáján. Vizsgáljuk a BIPQ megbízhatósági mutatóit, validitását. A konstruktumvaliditás ellenőrzése céljából felmértük a páciensek érzelmi és hangulati állapotát, illetve a poszttraumás növekedésérzés és az életminőség mértékét. A prediktív validitás igazolására a vesetranszplantáción átesett pácienseknél rögzítettük az eGFR-szintet, mivel feltételeztük, hogy a negatívabb betegségpercepció kapcsolatban áll a beültetett vese múködését jelző laboratóriumi értékekkel. A diszkriminatív validitás igazolásához 11 betegcsoportot hasonlítottunk össze.

\section{Módszer}

\section{A résztvevók és a vizsgálat körülményei}

A kérdőív pszichometriai tulajdonságainak vizsgálatához az alábbi 11 betegcsoport adatait vizsgáltuk: colitis ulcerosa (58 fó), krónikus veseelégtelenség (36 fö), emlődaganat (61 fó), Parkinson-kór (10 fó), stroke (25 fó), tinnitus (148 fó), rectumtumor (30 fó), colontumor (18 fó), tüdőtumor (30 fö), vesetranszplantáció (40 fó), HIV (34 fó) (1. táblázat). A pácienseket a Szegedi Tudományegyetem Szent-Györgyi Albert Klinikai Központjában toboroztuk (18 évesnél idősebb, krónikus vagy daganatos megbetegedéssel diagnosztizált, illetve transzplantáción átesett betegek), kivéve a tinnitusszal diagnosztizált pácienseket, akiket online kérdőív útján értünk el. A tesztcsomag kitöltése önkéntes alapon történt. A vesefunkciós értékek nyomon követéséhez rögzítettük a kontrollvizsgálatra érkezés napján, vagyis a tesztkitöltés napján történt vérvizsgálat eredményei közül az eGFR-szintet, hogy értékelni tudjuk a transzplantáció sikerességét. A kutatást a Regionális Humán Orvosbiológiai Kutatásetikai Bizottság engedélyezte (protokoll- 
1. táblázat |A betegcsoportok részletes bemutatása

\begin{tabular}{lccc}
\hline Betegcsoport & $\mathrm{n}$ & $\begin{array}{c}\text { Nem } \\
\text { (\% férfi) }\end{array}$ & $\begin{array}{c}\text { Átlagéletkor } \\
(\mathrm{SD})\end{array}$ \\
\hline Colitis ulcerosa & 58 & 50 & $43,11(10,77)$ \\
Colontumor & 18 & 61 & $64,22(15,03)$ \\
Emlődaganat & 61 & 0 & $55,49(13,25)$ \\
HIV-pozitív & 34 & 9 & $43,55(12,38)$ \\
Krónikus veseelégtelenség & 36 & 55 & $44,86(12,15)$ \\
Parkinson-kór & 10 & 60 & $65,51(12,17)$ \\
Rectumtumor & 30 & 46 & $57,83(13,01)$ \\
Stroke & 25 & 44 & $65,84(7,39)$ \\
Tinnitus & 148 & 26 & $47,56(13,56)$ \\
Tüdőtumor & 30 & 56 & $61,83(9,92)$ \\
Vesetranszplantáció & 40 & 50 & $49,35(10,13)$ \\
\hline Összesen & 490 & 40 & $51,11(14,18)$ \\
\hline
\end{tabular}

SD = standard deviáció

szám: 130/2016-SZTE). A mintából 17 fó nem vagy hiányosan töltötte ki a kérdőíveket; az ő adataikat a statisztikai elemzéskor figyelmen kívül hagytuk. Összesen 490, krónikus betegséggel küzdő páciens került a mintába (199 férfi, átlagéletkoruk 50,31 év; SD = 14,88; illetve 291 nő, átlagéletkoruk 51,64 év; SD = 13,68).

\section{Pszichológiai méröeszközök}

BIPQ - A Rövid Betegségpercepció Kérdőív nyolc fó dimenziót különít el a betegséghez való hozzáállásban [10]. A következmények dimenzió arra vonatkozik, hogy mennyire befolyásolja a személy életét a betegsége, míg az időbeliség dimenzió segítségével megtudhatjuk, hogy a személy mit gondol, milyen hosszú ideig fog tartani a betegsége. A személyes kontroll arra vonatkozik, hogy a páciens mennyire tudja befolyásolni saját betegségét, míg a kezelési kontroll azt jelenti, hogy mennyire látja hatásosnak a kapott orvosi kezelést a betegsége gyógyításában. Az identitás dimenzió arra kérdez rá, hogy mennyi tünetet okoz a betegség, a koherencia dimenzió pedig arra vonatkozik, hogy a személy mennyire érzi úgy, hogy érti saját betegségét. Végül az aggodalom és az érzelmi reprezentáció arra kérdez rá, hogy mennyire aggasztja a személyt a betegsége, és érzelmileg mennyire van hatással rá. Mindezek mellett egy 9. kérdés is szerepel a kérdőívben, amely arra kérdez rá, hogy a személy szerint milyen okok állhatnak betegségének hátterében. A válaszokat kategorizálhatjuk, például stressz, életmód, genetika stb. szempontjából, és tovább elemezhetjük. Továbbá a dimenziókból létrehozható egy összpontszám, ha összeadjuk az 1., 2., 5., 6. és 8. kérdésre adott válaszok pontszámait, majd a 3., 4. és 7. fordított tételek pontszámait. Ez az összpontszám a betegséggel kapcsolatosan észlelt fenyegetettséget adja meg, mely minél magasabb, annál negatívabb a betegségről kialakított kép.
BDI - A Beck Depresszió Kérdőív 21 tételes változatát alkalmaztuk, mely 4 fokú Likert-skálán a depresszió egyes tüneteire kérdez rá, úgymint fáradékonyság, alvászavar, döntésképtelenség, túlzott aggódás, az elégedettség hiánya, önmagunk vádolása [11, 12].

STAI - A Spielberger-féle Vonás- és Állapotszorongás Skála (STAI-T és STAI-S) 40 tételes kérdőív, mely a szorongás szintjének mérésére alkalmas; a vonásszorongásra vonatkozó kérdőív a szorongás általános szintjét méri, míg az állapotszorongásra vonatkozó az éppen aktuális szorongást jelzi. A kérdőív 4 fokú Likert-skálán mér [13, $14]$.

PTGI - A 21 tételes Poszttraumás Növekedésérzés Kérdőív a traumatikus eseményekkel való megküzdés során bekövetkező lehetséges pozitív változásokat tartalmazza $[15,16]$. A válaszadók hatfokozatú Likert-skálán értékelik, hogy mennyire jellemző rájuk az adott állítás. Az összesített pontszám a poszttraumás növekedésérzés mértékeként értelmezhető.

FACT-G - Az egészséggel összefüggő életminőséget a 27 állítást tartalmazó Functional Assessment of Cancer Therapy - General magyar változatával mértük [17]. Ezt a kérdő́vet azért fejlesztették ki, hogy bármilyen típusú rákos megbetegedés esetén képes legyen mérni az onkológiai kezelésben részesülő betegek életminőséget. A kérdőív 27 állításból áll, amelyek 4 alskálába tömörülnek: Fizikai jóllét, Társas/Családi jóllét, Érzelmi jóllét és Funkcionális jóllét. A magasabb összpontszám az egészséggel összefüggő jobb életminőséget tükröz.

GIQLI - A Gastrointestinalis Életminőségi Indexszel (Gastrointestinal Quality of Life Index) jellemeztük a colitis ulcerosával diagnosztizált pácienseink életminőségét [18]. 36 kérdésből áll, melyek az életminőséget pszichoemocionális, fizikai és szociális oldalról közelítik meg, emellett általános emésztőszervi panaszokkal kapcsolatos kérdéseket is tartalmaz.

EQ-5D-3L - Az általános életminőség-kérdőívek egyik legismertebb és leggyakrabban használt képviselője a European Quality of Life [19, 20]. A kérdőív 5 dimenziót vizsgál: mozgásképesség, önellátás, szokásos napi tevékenységek elvégzése, fájdalom/rossz közérzet, valamint szorongás/lehangoltság. A kérdőíven minden dimenzióra egy kérdés vonatkozik, melyet 3 fokú skálán kell megítélni.

\section{Statisztikai eljárások}

A statisztikai elemzést az SPSS 23-as verziójával (IBM Corporation, Armonk, NY, Amerikai Egyesült Államok) végeztük. A statisztikai szignifikancia határát a $\mathrm{p}<0,05$ ös szinten határoztuk meg. Az adatok elemzéséhez megvizsgáltuk a STAI, a BDI, a PTGI és az életminőségkérdőíveket, és a BIPQ skáláinak normális eloszlását Shapiro-Wilk-féle normalitásvizsgálattal is áttekintettük. A kérdőív belső megbízhatóságát a Cronbach-alfa mérőszámmal jellemeztük. A konkurens validitás megállapítására Pearson- és Spearman-féle korrelációt számítottunk. 
A Rövid Betegségpercepció Kérdőív magyar változata és kiértékelési útmutatója

Kérjük, karikázza be azt a számot, amelyik a legjobban megfelel az Ön véleményének.

1) Mennyire van hatással betegsége az életére?

$\begin{array}{ccccccccccc}0 & 1 & 2 & 3 & 4 & 5 & 6 & 7 & 8 & 9 & 10 \\ \begin{array}{c}\text { egyáltalán nincs } \\ \text { hatással }\end{array} & & & & & & & & & & \end{array}$

2) Mit gondol, a betegsége mennyi ideig fog tartani?

$\begin{array}{ccccccccccc}0 & 1 & 2 & 3 & 4 & 5 & 6 & 7 & 8 & 9 & 10 \\ \text { örökké }\end{array}$

nagyon rövid ideig

3) Mennyire tudja befolyásolni a betegségét?

semmiféle befolyásom

123

nincs felette

$\begin{array}{llllll}4 & 5 & 6 & 7 & 8 & 9\end{array}$
magas kontrollom van felette

4) Mit gondol, mennyire hatásos a kezelés a betegsége gyógyításában?

$\begin{array}{cccccccccccc}0 & 1 & 2 & 3 & 4 & 5 & 6 & 7 & 8 & 9 & 10 \\ \text { nem igazán hatásos } & & & & & & & & & & & \end{array}$

\section{5) Mennyi tünetet okoz a betegsége?}

$$
\begin{array}{lll}
0 & 1 & 2
\end{array}
$$

egyáltalán nincsenek

$$
\text { tünetek }
$$

6

7

8

9

10

sok súlyos tünetet

okoz

\begin{tabular}{|c|c|c|c|c|c|c|c|c|c|c|}
\hline $\begin{array}{c}0 \\
\text { egyáltalán nem } \\
\text { aggódom }\end{array}$ & 1 & 2 & 3 & 4 & 5 & 6 & 7 & 8 & 9 & $\begin{array}{l}10 \\
\text { kifejezetten } \\
\text { aggódom }\end{array}$ \\
\hline \multicolumn{11}{|c|}{ Mit gondol, mennyire érti a betegségét? } \\
\hline 0 & 1 & 2 & 3 & 4 & 5 & 6 & 7 & 8 & 9 & 10 \\
\hline $\begin{array}{l}\text { egyáltalán nem } \\
\text { értem }\end{array}$ & & & & & & & & & & $\begin{array}{l}\text { nagyon tisztán } \\
\text { értem }\end{array}$ \\
\hline
\end{tabular}

6) Mennyire aggódik a betegsége miatt?

8) Érzelmileg mennyire van hatással Önre a betegsége? (Például aggasztja, félelemmel tölti el, nyugtalanná, lehangolttá teszi.)

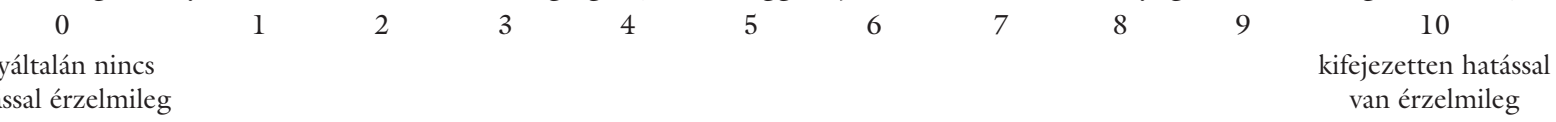

9) Rangsorolja azt a 3 legfontosabb tényezőt, melyet Ön a betegsége lehetséges okainak vél.

A legfontosabb okok számomra:

1 .

2 .

3.

A Rövid Betegségpercepció Kérdőív kiértékelése

A BIPQ mindegyik tétele a betegségpercepció egy dimenzióját értékeli.

A következmények pontszáma az l. kérdésre adott válasz.

Az időbeliség dimenziója a 2. kérdésre adott válasz.

A személyes kontroll a 3. kérdésre adott válasz.

A kezelési kontroll a 4 . kérdésre adott válasz.

Az identitás dimenziója az 5. kérdésre adott válasz.

A koherencia pontszáma a 7 . kérdésre adott válasz.

$\mathrm{Az}$ érzelmi reprezentáció a 8. kérdésre adott válasz.

A betegséggel kapcsolatos aggodalmat a 6. kérdés méri, mely az érzelmi és a kognitív reprezentációk kombinációja.

A 9. tétel a betegség lehetséges okaira kérdez rá. A válaszokat kategorizálhatjuk, például stressz, életmód, genetika stb., és tovább elemezhetjük.

A dimenziókból létrehozható egy összpontszám, ha összeadjuk az 1., 2., 5., 6. és 8. kérdésre adott válaszok pontszámait, majd a 3., 4. és 7 . fordított tételek pontszámait. Ez az összpontszám a betegség észlelt fenyegetettségét adja meg, mely minél magasabb, annál negatívabb a betegségről kialakított kép.

A kérdőívben szereplő „betegség” szót kicserélhetjük az adott betegségre, például cukorbetegség vagy asztma. Hasonlóan, a „kezelés” szó helyettesíthető az adott kezeléssel, például inhalálókészülék vagy mútét. 
A csoportok összehasonlítására egyszempontos ANOVA-t, kétmintás t-próbát, illetve Mann-Whitney-tesztet alkalmaztunk.

\section{Eredmények}

\section{A megbizhatóság vizsgálata}

Mérőskáláink megbízhatóságát a belső konzisztencia megállapítására legelfogadottabb mérőszámmal, a Cronbach-féle alfa-együttható meghatározásával ellenőriztük [21]. A kérdőív vizsgálatakor elért alfa-érték 0,613 volt, mely az attitűdskálák esetében megfelelő belső megbízhatóságra utal. A BIPQ teszt-reteszt megbízhatósága négyhetes, féléves és egyéves újrafelvétel után kiváló volt ( $\mathrm{n}=19$ transzplantált páciens; egy hó: $\mathrm{r}=0,603, \mathrm{p}=$ 0,006; fél év: $r=0,755, p<0,001$; egy év: $r=0,549, p=$ 0,022 ), azaz a kérdóív időbeli megbízhatósága is megfelelő. Továbbá az elemzés alapján nincsenek redundáns kérdések a kérdőívben, az egyes tételek közötti korreláció nem haladta meg az $\mathrm{r}=0,9$-es értéket.

\section{Validitásvizsgálat}

A résztvevők a mérőeszközt érthetőnek találták, ami a tesztkitöltési motivációt, az együttmúködési hajlandóságot is növeli. A validitásvizsgálatba bevont skálák között szerepel az Állapot- és Vonásszorongás Kérdőív, a Beck Depresszió Kérdőív, a Poszttraumás Növekedés Kérdőív és az életminőség-kérdőívek. A konvergens validitás esetében a BIPQ és a BDI $(\mathrm{r}=0,542, \mathrm{p}<0,001)$, illetve a
STAI-T $(\mathrm{r}=0,508, \mathrm{p}<0,001)$ és a STAI-S $(\mathrm{r}=0,45 \mathrm{l}$, p<0,001) kérdőív között közepesen erôs korreláció mutatkozott. A BIPQ a PTGI 'Személyes erő' $(r=-0,213$, $\mathrm{p}=0,021)$ skálájával mutatott szignifikáns összefüggést.

A daganatos páciensek körében a FACT-G kérdőívet alkalmaztuk, mely kérdőív az alskáláival együtt közepesen erôs korrelációt mutatott a BIPQ-vel $(\mathrm{p}<0,001)$. A colitis ulcerosával diagnosztizált páciensek körében alkalmazott GIQLI kérdőív összpontszáma pedig erôs korrelációt mutatott a BIPQ kérdóívvel $(\mathrm{r}=-0,842$, $\mathrm{p}<0,001)$. Az EQ-5D-3L kérdőív közepesen erős összefüggést mutatott a BIPQ-vel $(\mathrm{r}=0,522, \mathrm{p}<0,001)$.

A prediktív érvényesség vizsgálatakor szignifikáns öszszefüggés mutatkozott a BIPQ és a transzplantáció után a féléves kontrollvizsgálat alkalmával mutatott eGFR-érték között $(\mathrm{n}=40, \mathrm{r}=-0,35, \mathrm{p}=0,027)$. Eredményeink szerint tehát együttjárás tapasztalható a negatívabb betegségpercepció és az alacsonyabb eGFR-érték között, ami a transzplantált vese nem megfelelő múködését mutatja. A tételek közül az aggódás $(\mathrm{r}=-0,35, \mathrm{p}=0,024)$ és a kezelési kontroll $(\mathrm{r}=0,65, \mathrm{p}=0,002)$ mutatott szignifikáns összefüggést a vesefunkciót jelző laboratóriumi paraméterekkel. Tehát a páciens negatív érzelmi és kognitív reprezentációja és az orvosi kezeléssel kapcsolatos bizalom meggyengülése kapcsolatban állt a transzplantált vese diszfunkciójával.

Annak érdekében, hogy felmérjük, vajon a BIPQ alkalmas-e arra, hogy különbséget tegyen a különböző betegpopulációk között, a kérdőív skáláinak átlagértékét és az összesített BIPQ átlagát összehasonlítottuk a colitis ulcerosával, krónikus veseelégtelenséggel, emlődaganat-

2. táblázat |A Rövid Betegségpercepció Kérdőív átlagpontszámai (SD) a különböző betegcsoportokban $\left({ }^{* *}\right.$ p $\left.<0,001\right)$

\begin{tabular}{|c|c|c|c|c|c|c|c|c|c|c|c|c|}
\hline & $\begin{array}{c}\text { Colitis } \\
\text { ulcerosa }\end{array}$ & $\begin{array}{l}\text { Colon- } \\
\text { tumor }\end{array}$ & $\begin{array}{c}\text { Emlö- } \\
\text { daganat }\end{array}$ & $\begin{array}{l}\text { HIV- } \\
\text { pozitív }\end{array}$ & $\begin{array}{l}\text { Krónikus } \\
\text { veseelég- } \\
\text { telenség }\end{array}$ & $\begin{array}{l}\text { Parkinson- } \\
\text { kór }\end{array}$ & $\begin{array}{l}\text { Rectum- } \\
\text { tumor }\end{array}$ & Stroke & Tinnitus & $\begin{array}{l}\text { Tüdő- } \\
\text { tumor }\end{array}$ & $\begin{array}{c}\text { Vesetransz- } \\
\text { plantáció }\end{array}$ & $\mathrm{F}$ \\
\hline Hatás & $\begin{array}{r}6,2 \\
(3,1)\end{array}$ & $\begin{array}{r}6,5 \\
(3,2)\end{array}$ & $\begin{array}{r}5,9 \\
(3,1)\end{array}$ & $\begin{array}{r}4,5 \\
(3,1)\end{array}$ & $\begin{array}{r}6,8 \\
(3,1)\end{array}$ & $7,3(2,4)$ & $\begin{array}{r}5,8 \\
(3,1)\end{array}$ & $\begin{array}{r}6,3 \\
(2,3)\end{array}$ & $\begin{array}{c}5,1 \\
(2,6)\end{array}$ & $\begin{array}{r}4,6 \\
(3,4)\end{array}$ & $\begin{array}{c}4,1 \\
(2,9)\end{array}$ & 3,87 * * \\
\hline Időtartam & $\begin{array}{c}9,1 \\
(2,2)\end{array}$ & $\begin{array}{r}4,7 \\
(2,8)\end{array}$ & $\begin{array}{r}3,7 \\
(2,7)\end{array}$ & $\begin{array}{c}9,1 \\
(1,9)\end{array}$ & $\begin{array}{r}6,3 \\
(2,4)\end{array}$ & $9,9(0,3)$ & $\begin{array}{r}4,2 \\
(2,6)\end{array}$ & $\begin{array}{r}5,9 \\
(2,8)\end{array}$ & $\begin{array}{r}8,2 \\
(2,6)\end{array}$ & $\begin{array}{r}4,3 \\
(2,9)\end{array}$ & $\begin{array}{r}7,8 \\
(3,3)\end{array}$ & 27,69 ** \\
\hline Személyes kontroll & $\begin{array}{r}4,7 \\
(3,1)\end{array}$ & $\begin{array}{c}5,1 \\
(3,0)\end{array}$ & $\begin{array}{r}5,5 \\
(2,9)\end{array}$ & $\begin{array}{r}3,5 \\
(3,3)\end{array}$ & $\begin{array}{r}4,6 \\
(2,7)\end{array}$ & $5,1(3,2)$ & $\begin{array}{r}4,6 \\
(2,9)\end{array}$ & $\begin{array}{r}4,2 \\
(2,1)\end{array}$ & $\begin{array}{r}2,6 \\
(2,7)\end{array}$ & $\begin{array}{r}6,4 \\
(3,6)\end{array}$ & $\begin{array}{r}3,2 \\
(3,1)\end{array}$ & 8,26 ** \\
\hline Kezelési kontroll & $\begin{array}{r}3,5 \\
(3,3)\end{array}$ & $\begin{array}{r}2,4 \\
(2,7)\end{array}$ & $\begin{array}{r}3,3 \\
(2,8)\end{array}$ & $\begin{array}{r}1,7 \\
(2,3)\end{array}$ & $\begin{array}{r}1,6 \\
(1,7)\end{array}$ & $3,2(2,6)$ & $\begin{array}{r}3,3 \\
(3,5)\end{array}$ & $\begin{array}{r}4,1 \\
(2,5)\end{array}$ & $\begin{array}{r}1,3 \\
(2,3)\end{array}$ & $\begin{array}{r}2,5 \\
(2,3)\end{array}$ & $\begin{array}{r}1,3 \\
(2,1)\end{array}$ & 7,05 * * \\
\hline Tünetek & $\begin{array}{r}4,7 \\
(3,1)\end{array}$ & $\begin{array}{r}3,3 \\
(2,4)\end{array}$ & $\begin{array}{r}2,4 \\
(2,7)\end{array}$ & $\begin{array}{r}2,2 \\
(3,1)\end{array}$ & $\begin{array}{c}4,1 \\
(2,4)\end{array}$ & $6,1(2,6)$ & $\begin{array}{r}4,8 \\
(2,6)\end{array}$ & $\begin{array}{r}5,6 \\
(2,4)\end{array}$ & $\begin{array}{r}3,9 \\
(2,6)\end{array}$ & $\begin{array}{r}2,8 \\
(2,9)\end{array}$ & $\begin{array}{c}3,1 \\
(2,3)\end{array}$ & 6,53 ** \\
\hline Aggódás & $\begin{array}{c}5,1 \\
(3,2) \\
\end{array}$ & $\begin{array}{r}5,6 \\
(2,5) \\
\end{array}$ & $\begin{array}{r}5,9 \\
(3,1) \\
\end{array}$ & $\begin{array}{r}4,3 \\
(3,4) \\
\end{array}$ & $\begin{array}{r}5,6 \\
(3,1) \\
\end{array}$ & $5,7(1,8)$ & $\begin{array}{r}5,4 \\
(2,9) \\
\end{array}$ & $\begin{array}{r}5,4 \\
(2,5) \\
\end{array}$ & $\begin{array}{c}5,1 \\
(3,2) \\
\end{array}$ & $\begin{array}{c}5,1 \\
(3,1) \\
\end{array}$ & $\begin{array}{r}3,5 \\
(2,8) \\
\end{array}$ & 1,92 ** \\
\hline Koherencia & $\begin{array}{r}1,5 \\
(1,6)\end{array}$ & $\begin{array}{c}3,1 \\
(2,7)\end{array}$ & $\begin{array}{r}2,9 \\
(2,7) \\
\end{array}$ & $\begin{array}{r}0,9 \\
(1,6) \\
\end{array}$ & $\begin{array}{r}1,2 \\
(1,5)\end{array}$ & $2,8(1,9)$ & $\begin{array}{r}2,9 \\
(2,9) \\
\end{array}$ & $\begin{array}{r}3,2 \\
(2,3) \\
\end{array}$ & $\begin{array}{r}4,7 \\
(3,7) \\
\end{array}$ & $\begin{array}{r}5,2 \\
(3,3) \\
\end{array}$ & $\begin{array}{r}1,3 \\
(1,9) \\
\end{array}$ & 13,91 * * \\
\hline $\begin{array}{l}\text { Érzelmi reprezentá- } \\
\text { ció }\end{array}$ & $\begin{array}{r}5,3 \\
(3,4) \\
\end{array}$ & $\begin{array}{r}5,8 \\
(2,8) \\
\end{array}$ & $\begin{array}{r}6,6 \\
(2,8) \\
\end{array}$ & $\begin{array}{r}4,2 \\
(3,4) \\
\end{array}$ & $\begin{array}{r}5,3 \\
(2,8) \\
\end{array}$ & $6,1(1,8)$ & $\begin{array}{r}5,8 \\
(3,1)\end{array}$ & $\begin{array}{r}6,3 \\
(2,6)\end{array}$ & $\begin{array}{r}5,4 \\
(3,2)\end{array}$ & $\begin{array}{r}4,4 \\
(2,6)\end{array}$ & $\begin{array}{r}3,3 \\
(2,9)\end{array}$ & 3,84 * * \\
\hline BIPQ-összpontszám & $\begin{array}{c}40,1 \\
(14,6)\end{array}$ & $\begin{array}{l}36,7 \\
(9,3)\end{array}$ & $\begin{array}{c}35,6 \\
(12,7)\end{array}$ & $\begin{array}{c}30,2 \\
(13,7)\end{array}$ & $\begin{array}{c}34,9 \\
(11,3)\end{array}$ & $\begin{array}{l}46,3 \\
(7,4)\end{array}$ & $\begin{array}{c}36,9 \\
(13,1)\end{array}$ & $\begin{array}{c}41,1 \\
(13,7)\end{array}$ & $\begin{array}{c}36,3 \\
(11,1)\end{array}$ & $\begin{array}{c}35,4 \\
(13,9)\end{array}$ & $\begin{array}{c}27,5 \\
(12,4)\end{array}$ & 4,41 ** \\
\hline
\end{tabular}

BIPQ = Rövid Betegségpercepció Kérdőív; SD = standard deviáció 
tal, Parkinson-kórral, stroke-kal, tinnitusszal, rectum-, colon-, illetve tüdőtumorral diagnosztizált, továbbá vesetranszplantáción átesett és HIV-pozitív páciensek között (2. táblázat). A BIPQ diszkrimináns validitása 11 különböző betegcsoport adatait vizsgálva igazolódott, az észlelt különbségek összhangban voltak elvárásainkkal. Például a dializált, krónikus veseelégtelenséggel küzdő páciensek úgy érezték, hogy a betegség nagyobb hatással van az életükre, és negatívabb kép alakult ki bennük a már transzplantáción átesett vesebetegekhez képest. A tünetek észlelését tekintve a legemelkedettebb pontszám a Parkinson-kórral diagnosztizált populáción mutatkozott, ami szintén nem meglepő, hiszen a betegség négy alapvető tünete - a remegés, az izommerevség, a meglassultság és a testtartási instabilitás - az élet számos területén korlátozhatja a kliensek életét, megemelve a skála átlagértékét [22]. Ezzel szemben például a HIVpozitív vagy az emlődaganattal diagnosztizált páciensek sok esetben semmilyen tünetet nem észlelnek magukon, ami a skála alacsony pontszámát magyarázza.

\section{Összefüggés a szociodemográfiai változókkal}

A kérdőív összpontszáma nem különbözött jelentősen a férfiak és a nók között $(\mathrm{t}=0,61, \mathrm{p}=0,541)$. A BIPQ dimenzióit tekintve azonban a nók szignifikánsan alacsonyabb pontszámot értek el az időtartam $(Z=-2,515$, $\mathrm{p}=0,012)$ és a személyes kontroll $(\mathrm{Z}=-2,021, \mathrm{p}=$ $0,043)$ skáláján, míg a férfiak valamivel emelkedettebb értéket mutattak a koherencia skálája mentén $(\mathrm{Z}=$ $-2,001, \mathrm{p}=0,045)$. A kérdóív nem mutatott összefüggést az iskolai végzettséggel, a családi állapottal, a gyermekek számával vagy a gazdaságilag aktív/passzív szereppel (a p-érték minden esetben $>0,05$ ).

\section{A betegség vélt okai}

Az általunk validált kérdőív utolsó tétele arra kérdez rá, hogy a páciens szerint melyek lehetnek a betegsége lehetséges okai. Vizsgálati mintánkban a betegcsoportok között érdekes különbségek mutatkoztak. A colitis ulcerosával diagnosztizált páciensek 92\%-a úgy gondolta, hogy a betegség oka pszichológiai (például munkahelyi, párkapcsolati stressz, feszültség a családon belül). 42\%uk vélte úgy, hogy genetikai tényezők állnak a háttérben, míg 24 fó környezeti okokat is felsorolt (például egészségtelen táplálkozás vagy munkakörnyezet). A HIV-pozitív válaszadók genetikai tényezőket nem említettek, azonban 94\%-uk a betegség vélt okának valamilyen személyiségjegyet tulajdonított (például naivitás, kontrollhiány, felelőtlenség, határozatlanság). A legnagyobb arányban $(56,1 \%)$ a tinnitusszal küzdő páciensek gondolták úgy, hogy a tüneteket valamilyen testi elváltozás vagy betegség okozza (például magas vérnyomás, a nyaki erek állapota, középfülgyulladás), 63,5\%-uk azonban a pszichológiai tényezők szerepét is kiemelte (például az önismeret hiánya, lelki fáradtság), míg 20,9\%-uk környe- zeti okokat vélt felfedezni a betegsége mögött (például zajártalom). Az emlődaganattal diagnosztizált páciensek 59\%-a pszichológiai okot említett (például stressz, idegesség), 18\%-uk genetikai, örökletes tényezőket is, míg 36\%-uk kiemelte a mozgásszegény életmód és a helytelen táplálkozás szerepét. A rectumtumorral operált páciensek 63\%-a lelki tényezőket sorolt fel, melyek a betegségük kialakulásának okai lehetnek, 27\%-uk örökletes és 36\%-uk környezeti okokat is említett. A colontumorral diagnosztizált válaszadók 61\%-a lelki tényezőket írt, míg 22\%-uk örökletes és 27\%-uk környezeti faktorokat. A krónikus veseelégtelenséggel küzdő páciensek 56\%-a pszichológiai okot tulajdonított betegségének, 29\%-uk kiemelte a környezeti faktorok szerepét, míg 39\%-uk genetikai tényezóket is említett. A tüdőtumorral operált páciensek a legnagyobb arányban a dohányzás és a nem megfelelő egészségmagatartás szerepét emelték ki (50\%), de megjelent a lelki tényezők (20\%) és az örökletes faktorok (13\%) hatása is. A stroke-kal kezelt betegek 32\%-a pszichológiai okokat említett, 8\%-uk genetikai tényezőket, míg 44\%-uk környezeti tényezőket. A Parkinsonkórral kezelt páciensek fele úgy gondolta, hogy a betegségük mögött genetikai tényező áll, míg 10\%-uk pszichológiai és szintén 10\%-uk környezeti tényezőket is említett.

\section{Megbeszélés}

Tanulmányunkban a betegséggel kapcsolatos kognitív és érzelmi reprezentációk mérésére alkalmazható, 9 tételes BIPQ magyar változatát mutattuk be. A kutatás során 11 betegcsoportnál felmértük az érzelmi és a hangulati állapotot, a poszttraumás növekedésérzés mértékét és az életminőséget. A prediktív validitás igazolásához a pszichológiai változókat összevetettük a beültetett vese múködését jelző eGFR-szinttel. A páciens negatív érzelmi és kognitív reprezentációja és az orvosi kezeléssel kapcsolatos bizalom meggyengülése kapcsolatban állt a transzplantált vese diszfunkciójával. Hasonlóan fontos eredményre jutottak Broadbent és mtsai [10] is, akik a 2-es típusú cukorbetegséggel diagnosztizált páciensek körében a magas kezelési kontroll és a vércukorszint között találtak szignifikáns összefüggést, a myocardialis infarctusból gyógyuló pácienseknél pedig a munkába való viszszatérést jósolta meg a kezelési kontroll dimenziója.

Az eredményekből megállapíthatjuk, hogy a kérdőív pszichometriai mutatói megfelelőek, az általunk mért belső konzisztencia jónak mondható. A kérdőív teszt-reteszt megbízhatósága kiváló, vagyis a kérdőív időbeli megbízhatósága is megfelelő. Mintánkban a BIPQ-összpontszámot a nem, a kor és az iskolai végzettség nem befolyásolta szignifikánsan. Ugyanakkor a validitás vizsgálatakor több, gyenge mértékú korrelációt találtunk a kérdőív és az érzelmi-hangulati állapot, illetve a poszttraumás növekedésérzés és az életminőség között. A diszkrimináns validitás eredményei tehát a mérőeszköz érvényességét erősítik, mivel nem mutatott túlzott mértékű 
egyezést a többi pszichológiai kérdőívvel, melyek más fogalmi konstruktumok mérésére szolgálnak.

Összességében a kutatócsoportunk által magyar nyelvre adaptált BIPQ magyar verziójának pszichometriai mutatói igen jók, a kérdőív skálái és összpontszáma megbízható információt ad számunkra a páciensnek a betegséggel kapcsolatos kognitív és érzelmi reprezentációiról. A kérdőív gyorsan felvehető, egyszerúen kiértékelhető, továbbá alkalmas az egyes betegcsoportok összehasonlítására, a rizikószemélyek kiszúrésére, illetve a felépülés hosszú távú nyomon követésére.

Vizsgálatunk a pszichológiai intervenció fontosságára is felhívja a figyelmet, hiszen interdiszciplináris kutatások igazolták, hogy a páciensek betegségpercepciói, a betegséggel kapcsolatos félelmek és szorongások hátráltathatják a fizikális és pszichés felépülést egyaránt $[1,2,10$, 23]. A skálák értelmezése a terápiás folyamatot segítheti, hiszen a megemelkedett tételek mentén célzottan tudjuk csökkenteni a páciens negatív betegségpercepcióját, ami hosszú távon növelheti a gyógyulási esélyeit.

Anyagi támogatás: A közlemény megírása, illetve a kapcsolódó kutatómunka anyagi támogatásban nem részesült.

Szerzői munkamegosztás: L. M.: A kutatás megtervezéséért, az adatgyüjtésért, az adatok statisztikai értelmezéséért és a publikáció megírásáért volt felelős. L. Gy.: A kutatási terv kidolgozásában és az adatgyưjjtés lefolytatásában vett részt. Cs. M.: A kutatási terv kidolgozásában, az eredmények értelmezésében és a kézirat megírásában nyújtott segítséget. A cikk végleges változatát valamenynyi szerző elolvasta és jóváhagyta.

Érdekeltségek: A szerzőknek nincsenek érdekeltségeik.

\section{Irodalom}

[1] Griva K, Myers LB, Newman S. Illness perceptions and self efficacy beliefs in adolescents and young adults with insulin dependent diabetes mellitus. Psychol Health 2000; 15: 733-750.

[2] Moss-Morris R, Weinman J, Petrie KJ, et al. The Revised Illness Perception Questionnaire (IPQ-R). Psychol Health 2002; 17: $1-16$.

[3] Petrie KJ, Broadbent E, Meechan, G. Self-regulatory interventions for improving the management of chronic illness. In: Cameron LD, Leventhal H. (eds.) The self-regulation of health and illness behaviour. Routledge, New York, 2003; pp. 257-277.

[4] Leventhal H, Nerenz DR, Steele DJ. Illness representations and coping with health threats. In: Baum A, Taylor SE, Singer JE. (eds.) Handbook of psychology and health. Vol. IV. Social psychological aspects of health. Routledge, New York, NY, 1984; pp. 219-252.

[5] Petrie KJ, Cameron LD, Ellis CJ, et al. Changing illness perceptions after myocardial infarction: an early intervention randomized controlled trial. Psychosom Med. 2002; 64: 580-586.
[6] Sacks CR, Peterson RA, Kimmel PL. Perception of illness and depression in chronic renal disease. Am J Kidney Dis. 1990; 15: 31-39.

[7] Kimmel PL. Just whose quality of life is it anyway? Controversies and consistencies in measurement of quality of life. Kidney Int. 2000; 57: S113-S120.

[8] Kimmel PL, Peterson RA, Weihs KL. Psychosocial factors, behavioral compliance and survival in urban hemodialysis patients. Kidney Int. 1998; 54: 245-254.

[9] Weinman J, Petrie KJ, Moss-Morris R, et al. The Illness Perception Questionnaire: a new method for assessing the cognitive representation of illness. Psychol Health 1996; 11: 431- 445.

[10] Broadbent E, Petrie KJ, Main J, et al. The Brief Illness Perception Questionnaire. J Psychosom Res. 2006; 60: 631-637.

[11] Beck AT, Ward CH, Mendelson M, et al. An inventory for measuring depression. Arch Gen Psychiatry 1961; 4: 561-571.

[12] Rózsa S, Szádóczky E, Füredi J. Characteristics of the Beck Depression Scale in Hungarian sample. [A Beck Depresszió Kérdőív rövidített változatának jellemző́i hazai mintán.] Psychiatr Hung. 2001; 16: 384-402. [Hungarian]

[13] Sipos K, Sipos M, Spielberger CD. Hungarian version of the State-Trait Anxiety Inventory (STAI). In: Mérei F, Szakács F. (eds.) Psychodiagnostic Vademecum, I. Explorational and biographic methods, symptom evaluation scales and questionnaires, 2. [A State-Trait Anxiety Inventory (STAI) magyar változata. In: Mérei F, Szakács F. (szerk.) Pszichodiagnosztikai Vademecum I. Explorációs és biográfiai módszerek, tünetbecslő skálák, kérdőívek, 2.] Tankönyvkiadó, Budapest, 1988; pp. 123-136. [Hungarian]

[14] Spielberger CD, Gorsuch RL, Lushene RE. Manual for the State-Trait Anxiety Inventory. Consulting Psychologists Press, Palo Alto, CA, 1970.

[15] Kovács É, Balogh P, Preisz L. Psychometric characteristics of the Posttraumatic Growth Inventory in a Hungarian sample. [A Poszttraumás Növekedésérzés Kérdő́ív pszichometriai mutatói hazai mintán.] Mentálhig Pszichoszom. 2012; 13: 57-84. [Hungarian]

[16] Tedeschi RG, Calhoun LG. The Posttraumatic Growth Inventory: measuring the positive legacy of trauma. J Trauma Stress 1996; 9: 455-471.

[17] Eremenco S, Chang $\mathrm{CH}$, Lent L, et al. Psychometric equivalence evaluation of five non-western-language translated versions of the Functional Assessment of Cancer Therapy - General (FACT-G) version 4. Value Health 1999; 2: 362.

[18] Eypasch E, Williams JI, Wood-Dauphinee S, et al Gastrointestinal Quality of Life Index: development, validation and application of a new instrument. Br J Surg. 1995; 82: 216-222.

[19] Brooks R. EuroQol: the current state of play. Health Policy 1996; 37: 53-72.

[20] Szende A, Németh R. Health-related quality of life of the Hungarian population. [A magyar lakosság egészségi állapothoz kapcsolódó életminősége.] Orv Hetil. 2003; 144: 1667-1674. [Hungarian]

[21] Cronbach LJ. Essentials of psychological testing (5th edn). Harper \& Row, New York, NY, 1990.

[22] Pásztor E, Vajda J. Neurosurgery. [Idegsebészet.] Medicina Könyvkiadó, Budapest, 1995. [Hungarian]

[23] Broadbent E, Ellis CJ, Thomas J, et al. Further development of an illness perception intervention for myocardial infarction patients: a randomized controlled trial. J Psychosom Res. 2009; 67: $17-23$

(Látos Melinda dr., Szeged, Semmelweis u. 8., 6720 e-mail: latos.melinda@med.u-szeged.hu)

A cikk a Creative Commons Attribution 4.0 International License (https://creativecommons.org/licenses/by/4.0/) feltételei szerint publikált Open Access közlemény, melynek szellemében a cikk bármilyen médiumban szabadon felhasználható, megosztható és újraközölhető, feltéve, hogy az eredeti szerző és a közlés helye, illetve a CC License linkje és az esetlegesen végrehajtott módosítások feltüntetésre kerülnek. (SID_1) 